\title{
INVESTIGATING MOBILITY PATTERNS FOR REPETITIVE SEXUAL CONTACT IN ADULT CHILD SEX OFFENDING*
}

Benoit Leclerc, PhD

Richard Wortley, PhD

Stephen Smallbone, $\mathrm{PhD}$

School of Criminology and Criminal Justice

Mt Gravatt campus, Griffith University

Brisbane, Queensland 4111

Australia

*Please send correspondence to: Benoit Leclerc, School of Criminology and Criminal Justice, Mt Gravatt Campus, Griffith University, Queensland 4111, Australia; Tel: +61 (7) 3735 5755; Fax: +61 (7) 3735 5608; email: b.leclerc@griffith.edu.au. 


\section{INVESTIGATING MOBILITY PATTERNS FOR REPETITIVE SEXUAL CONTACT IN ADULT CHILD SEX OFFENDING}

\section{ABSTRACT}

In the present study, geographic mobility exhibited by child sex offenders was examined. Geographic mobility was defined as the use of multiple locations to obtain repetitive sexual contact with the same victim. The sample consisted of 77 adult offenders convicted for having committed a sexual offence against a child, and who agreed to provide confidential self-report data concerning their offending behaviours. Based on a set of offence characteristics, offenders who used a single location were compared to offenders who used multiple locations for sexual contact. Results showed that offenders who used multiple locations are more likely to isolate the victim, use violence, involve the victim in several sexual episodes, abuse the victim for a period exceeding one year, and make the victim participate and perform sexual behaviours on them during sexual episodes. Examining more closely offenders who used multiple locations for abuse, three offence patterns were further identified (i.e., familial-low mobility offence, non familial-high mobility offence, and familial-high mobility offence). Going for a car ride was also found to be a common location/situation used in the familial-low mobility offence subgroup, while the use of outdoor locations on a regular basis was found to be rare in high mobility patterns subgroups.

KEY WORDS: Journey to crime, geographic mobility, location of crime, offender decision-making, modus operandi, child sexual abuse. 


\section{INTRODUCTION}

Geographic mobility of offenders usually refers to distances travelled by offenders from their own home to crime locations, or the direction taken from their trip starting point (e.g., moving from the suburb to the city centre) (Brantingham \& Brantingham, 1984; Eck \& Weisburd, 1995; Rengert, 2004). Two important findings have emerged from journey-to-crime literature (for a extensive review, see Rossmo, 2000). First, crime was found to occur in close proximity to the offender's home which suggests that offenders tend to travel short distances in order to commit their crimes. This finding further suggests that most offenders will try to minimize their effort and choose the opportunity that requires the shortest distance to be travelled, a strategy which is referred to as the least-effort principle (Zipf, 1950). Second, it was found that distances travelled by offenders to commit their crimes vary according to the type of offence being committed. In general, violent crimes, such as rape and assault, were found to be more likely to be committed closer to the offender's home than property crimes such as burglary and robbery (Block, Galary, \& Brice, 2007; Gabor \& Gottheil, 1984, LeBeau, 1987; Rhodes \& Conly, 1981). Recently, Block et al. (2007) also found that, except for commercial robbery, distances travelled by offenders were short for rape, personal robbery and aggravated assault. Violent crimes were also found to occur close to the home of the victim (not only the home of offender). According to Block and his colleagues, this latter crime pattern perhaps emerges because routine activities of both the offender and the victim share the same space, that is, close to their home. As argued by Brantingham and Brantingham, "Routine activity space places people in situations, both physically and temporally, where crime triggering events are more or less likely to occur’' (1993, p.269). 
In the child sex offending area, Duwe, Donnay and Tewksbury (2008) completed a study on the spatial behaviours of 224 sex offenders who were reincarcerated for having committed a new sex offence against a victim less than eighteen years old. In most cases, offenders committed their offence near or in their home. Duwe and his colleagues also examined the distance between the offender residence and the offence location distance by the type of offender-victim relationship. In stranger cases, they found that 28 percent of reoffences occurred in offender's home and 23 percent took place within one mile of the offender's home. They also noted that in more than half of the total sample, the new offence took place in the offender's home. The percentage of cases occurring in the offender's home was greater for those who abused their significant other's son or daughter (89 percent), a biological family member (81 percent), or an acquaintance (74 percent).

Analysing serial sexual assaults in New Zealand, Lundrigan and Czarnomski (2006) examined if offenders have a tendency to travel farther as they abuse more victims. Their sample included child sex offenders, but mostly comprised offenders against adult women. No specific trend was found. In 49 percent of the series of victim, the first offence was closest to home, in 26 percent of cases, the second offence was the closest to home and in 35 percent of cases, the third offence was closest to home. With a sample of serial sex offenders (including - but not only - child sex offenders), Beauregard, Proulx, Rossmo, Leclerc and Allaire (2007) conducted a study to identify crime commission scripts for this population. The types of location (e.g., indoor versus outdoor locations) were found to be related to the types of strategy exhibited by an offender during the crime commision process. It was also found that sex offenders may switch from one place to another according to the stage of the crime commission process. 
For instance, in some cases, the location where the offender first encountered the victim was different from the place where the sexual contact took place.

Even though these studies provided clues to better understand the geographic mobility of child sex offenders, there is no available research that examines the use of multiple locations to obtain repetitive sexual contact with the same victim. This is surprising as new legislation, such as residency restrictions, have generated a growing interest in examining residential locations of child sex offenders (e.g., Duwe et al., 2008; Tewksbury \& Mustaine, 2006; Walker, Golden, \& VanHouten, 2001). In the present study, geographic mobility of child sex offenders is examined from another point of view. Geographic mobility is defined as the use of multiple locations to obtain repetitive sexual contact with the same victim.

\section{THEORETICAL BACKGROUND}

Environment criminology and crime analysis emphasize the understanding and prevention of crime events. This area of research mainly originated from three theoretical approaches - routine activity, rational choice and crime pattern theory. Each of these perspectives treats opportunities for offending as fundamental to better understand crime. Moreover, each is interested in examining crime events, offender decision-making, and crime-commission processes.

The routine activity approach (Cohen \& Felson, 1979) suggests that crime occurs when three elements converge in time and space: a motivated offender; a suitable target/victim; and the absence of capable guardianship, that is, anybody whose presence or proximity could discourage an offender from committing a crime. Building on Felson`s (1986) work, Eck (1995) updated this perspective by focusing on places and proposing the concept of place managers (see also Felson, 1995). There 
are three objects of supervision to reduce crime opportunities: the offender, the suitable target and the amenable place for crime to occur. If offenders are supervised by handlers, targets by guardians, and places by managers, crime is less likely.

The rational choice approach (Cornish \& Clarke, 1986; 2008) is mostly concerned with decision-making and behaviours at the time of crime commission. At its core is the concept that criminal behaviour is purposive. Offenders are viewed as engaging in crime to derive some benefits (e.g., money, vengeance, sexual gratification). Offenders engage in crime after having completed a cost-benefit analysis when encountering a crime opportunity. The decision to commit a crime, however, is constrained by the offender's cognitive abilities, availability of relevant information and time pressure. Still, offenders generally attempt to minimize their risks of apprehension and maximize their gains.

Brantingham and Brantingham (1978; 1984) developed a theoretical model of criminal behaviour within the environment. According to this model, the motivated offender interacts with the environment from which a suitable target or victim is selected. "Decisions about how to travel and where to travel are based on knowledge of the area, previous experience (which is tied to knowledge), and expectations about the result of travelling', (Brantingham \& Brantingham, 1984, p.338). The environment emits cues or signals about its related characteristics (e.g., spatial, physical), and the offender uses these cues to locate and identify potential targets or victims. From experience, the offender will develop cognitive images of his environment, that is, a template which will guide him through his search process. The search for a victim is completed through the offender's awareness space, which includes the activity space (i.e., the area where most activities are carried out by a person), and consists of all locations about which a person 
has some degree of knowledge (Brantingham \& Brantingham, 1993). In the following section, the location of the crime in relation to child sex offending is discussed.

\section{THE LOCATION OF CRIME ISSUE IN CHILD-SEX OEFFENDING}

During the crime-commission process, offenders, in interaction with their environment, need to make a number of decisions, one of which relates to the location of crime (Cornish, 1994). Offenders can plan to use a particular location for specific purposes (e.g., minimize their risks of apprehension) or simply make a decision onthe-spot because they do not have or see other possible alternatives. Studies emphasizing the offender decision-making process related to the location of the crime have been carried out for several types of property crime (e.g., burglary: Bennett \& Wright, 1984; Bernasco \& Nieuwbeerta, 2005; Coupe \& Blake, 2006; Cromwell, Olson, \& Avary, 1991; Nee \& Meenaghan, 2006; Rengert \& Wasilchick, 2000; Walsh 1986; Wright \& Decker, 1994; Wright \& Logie 1988; Wright, Logie, \& Decker, 1995; robbery: Feeney, 1986; Petrosino \& Brensilber 2003; Wright \& Decker, 1997; shoplifting: Carroll \& Weaver, 1986). In burglary, offenders must first decide on a suitable area and then select a specific home within that area. In child sex offending, the process is slightly different. When the victim has been selected, the offender must find a safe location for sexual contact. Contrary to burglary, the location is not the actual target. It has rather utilitarian purposes one of which is to have sexual contact with the victim without being seen and apprehended.

There are at least two notable differences between child sexual abuse and other crimes that have been studied in journey-to-crime research. First, the typical case of child sexual abuse involves an offender who knew his victim before the offence. In most cases, offenders were also living with their victim at the time of the offence. In such 
cases, the offender's home becomes a location where sexual contact between the offender and the victim can take place. Indeed, sexual offenses against children have been found to be committed in private as well as in public locations, but mostly in the offender's home (Elliott, Browne, \& Kilcoyne, 1995; Lang \& Frenzel, 1988; Wortley \& Smallbone, 2006). Second, child sexual abuse is different from most types of crime in that it has been found to involve a series of interconnected stages (e.g., gaining trust, gaining cooperation, maintaining silence) in which manipulation is used (Leclerc \& Tremblay, 2007; Leclerc, Wortley, \& Smallbone, 2008). Most often, the offender makes the victim participate in sexual episodes and the abuse takes place over weeks, months or even years. Over this period, the offender may use multiple locations for sexual contact. Figure 1 provides an illustration which highlights the difference between child sex offending and other types of crime usually studied in journey-to-crime research. For instance, an offender may commit a burglary which would involve a single event occurring in a single location. A child sex offender, however, may use several locations over a period of time in order to obtain repetitive sexual contact with the same victim. For instance, an offender may use four locations for different sexual episodes (i.e., his own home, a park, a playground, and a friend`s home for a total of twelve events) during the period of abuse. INSERT FIGURE 1

The main aim of this study is to better understand the offences perpetrated by sex offenders who used multiple locations to abuse the same victim over a period of time. It is believed that the concept of geographic mobility provides greater scope to study offending patterns of offenders than it might be assumed initially. This concept does not only refer to the concepts of distance or direction as currently used in the journey-tocrime literature. To better understand the crime-commission process of sex offenders, 
offending mobility can be analysed from other angles for different purposes. In this study, geographic mobility is defined as the use of multiple locations to obtain repetitive sexual contact with the same victim. Spatial behaviour is defined as travelling for the specific purpose of offending. The first question asked in this study is whether some offenders use multiple locations or locations other than their own home to perpetrate the abuse with the same victim. If some offenders are using multiple or other locations for abuse than their own home, this may offer other options for prevention purposes. For instance, as the offender's home may be the most difficult place in which to implement prevention measures (Smallbone, Marshall, \& Wortley, 2008), it might be worthwhile to focus on other types of location. In other words, these offenders may be reachable for prevention through other locations. Then, offenders who used a single location are compared to offenders who used multiple locations for sexual contact. The purpose is to examine whether offending differences exist between these two groups. The second question is whether different offending patterns can be identified within mobile offenders (i.e., those who used multiple locations for sexual contact). Once again, if different offence patterns exist within that group, it could help designers of prevention techniques to develop specific measures suitable for each subgroup.

\section{METHOD}

Sample

This study uses data from a large research project on child sex offenders in which the offender modus operandi was examined. Adult females who sexually abused children were not considered for this project. A total of 197 adult males who admitted committing a sexual offence against a child (sixteen years old or less) for which they were serving a sentence in Queensland (Australia) were included in this 
study. Most participants were serving a prison sentence (92.9 percent). The remaining participants were serving a community sentence (7.1 percent). A total of 64.6 percent of offenders had a prior record for committing an offence of any kind. Of the total sample, 102 participants sexually abused multiple victims and 94 abused a single victim only. This information was missing for one participant. Of the participants who abused multiple victims, 37.4 percent had a prior record for a sex offence. The remaining 62.6 percent of participants came to the attention of the authorities after having abused several victims.

As participants provided data on locations used overall (i.e., across all of their victims), it was not possible to link specific types of locations back to each victim for participants who abused multiple victims. Therefore, participants who only sexually abused one victim were considered ( $n=94)$. Seventeen of them, however, did not answer questions relating to the location for abuse when completing the questionnaire. Consequently, they were deleted from all analyses and the final sample size consisted of 77 offenders. On average, participants were 40.84 years old at assessment ( $S D=11.59$ ), and the majority (79.8 percent) was Australian born. Most of the participants did not achieve an education level higher than elementary school (87.1 percent). On average, participants were serving a sentence of 73.38 months ( $S D=45.11$, Range=12-213). Socio-demographic characteristics of participants who were excluded because they did not answer questions related to the location of abuse ( $n=17)$ were similar to those of participants included in this study. On average, excluded participants were 40.20 years old at assessment ( $\mathrm{SD}=15.51)$, and the majority (71.4 percent) was Australian born. Once again, most of these participants did not achieve an education level higher than elementary school (86.7 percent). On 
average, however, participants were serving a longer sentence (84.33 months, $\mathrm{SD}=72.27$, Range $=9-300)$.

Procedure

Each participant were approached individually by a member of the research team and agreed to complete a 386 items self-report questionnaire which analyzes offender modus operandi (MOQ) (Kaufman, 1989). Specifically, the MOQ is a selfreport instrument that provides a template to investigate the complete sequence of behaviours adopted prior to, during, and following the commission of a sexual offence against a child. It provides details on the sexual abuse which includes whether the offender made the victim participate and perform sexual behaviours on him during sexual episodes. It also includes information regarding the victim and situational factors. When completing the MOQ, participants were also asked to report the location(s) used to commit their acts during the period of abuse. Finally, they were asked to report the location(s) they most often used for that purpose. Previous work has reported that the test-retest reliability of the questions concerning offender modus operandi was acceptable. The average agreement rate for pre-offence behaviours was 89 percent, and for offence behaviours 92 percent. Generally, the MOQ was administered one-on-one by a research assistant. Before completing the questionnaire, participants were told that their involvement in this study was strictly voluntary. Each participant signed a consent form stating that the information would be used for research purposes only. They were assured that the information would be kept confidential and that records of names would be destroyed after data collection (for further details, see Smallbone \& Wortley, 2000). 


\section{ANALYTIC STRATEGY}

Although the Modus Operandi Questionnaire has been used to investigate child sex offenders’ behaviours (e.g., Kaufman, Hilliker, \& Daleiden, 1996; Leclerc et al., 2008; Leclerc \& Tremblay, 2007; Smallbone \& Wortley, 2000), it has never been used to uncover mobility patterns followed by these offenders. In that regard, this study is the first to use data from the MOQ in order to complete such an investigation. This study comprises two parts. In the first part, the sample was divided into two groups based on the number of locations used by offenders (i.e., offenders who used multiple locations and offenders who only used a single location for sexual contact). For each group, the number of offenders who used each location reported in this study was examined. Then, on the basis of offence characteristics, a comparison of these groups was performed. In the second part, the offending patterns exhibited by offenders who used multiple locations were further examined. Based on offence characteristics, three offence patterns were identified. The identification of these patterns initially followed two steps. A qualitative examination of offence characteristics revealed the presence of different offence patterns within mobile offenders. Even though the sample size is small, SPSS TwoStep cluster analysis was then used to support the initial examination. It provides a statistical validation of what was observed on a qualitative basis. This exploratory type of classification attempts to identify relatively homogeneous groups of cases based on selected characteristics. The optimal number of clusters was determined to be three. After having identified these offence patterns, a deeper examination of locations used in each pattern was also completed. 


\section{RESULTS}

Locations used by child sex offenders

Offenders were presented thirteen types of locations and asked to report which location(s) they used to perpetrate the abuse. The questionnaire contained the following locations: offender's home, out of the way place in child's home, friend/relative’s home, going for a car ride, isolated places outdoor, park, bush (i.e., forest), movie theatre, playground, public toilet, swimming pool, taking the child for walks, and taking the child other places. Table 1 shows that almost all offenders used their own home at some point in order to have sexual contact with their victim (84 percent). Then, using the child's home, taking the child for a car ride and using isolated place outdoors are the most common places used by offenders for abuse. Recall that an offender may have used several locations for sexual contact during the period of abuse.

INSERT TABLE 1

Single location versus multiple locations offenders

The sample was divided into two groups based on the number of locations used for sexual contact (i.e., offenders who used multiple locations and offenders who only used a single location for sexual contact). For each group, Figure 2 depicts the number of offenders who used each location reported in this study. It shows that almost all offenders who used multiple locations used their own home for abuse (23 out of 25, 92 percent). Then these offenders frequently went for a car ride with their victim (52 percent), used isolated places outdoor such as a vacant lot (48 percent), and isolated places in child's 
home (36 percent). Most single-location offenders used their own home for abuse (42 out of 52; 81 percent).

INSERT FIGURE 2

Offenders who used a single location were compared to offenders who used multiple locations for sexual contact (Table 2). Recall that a total of 25 offenders used multiple locations for sexual contact (32.5 percent). Compared to other offenders, these offenders are more likely to create and exploit circumstances for being alone with a child for sexual contact (i.e., isolation). Offenders using multiple locations are also more likely to use violence. Regarding the offence itself, these offenders are more likely to involve the victim in more than ten episodes over time and pursue with the abuse for over one year. Finally, these offenders are also more likely to make the victim participate and perform sexual behaviours during sexual episodes.

\section{INSERT TABLE 2}

Offending patterns of mobile offenders

As offence differences were found between offenders who used multiple locations and offenders who used a single location for abuse, an examination of offending patterns within the former group was performed (see Table 3). Following a qualitative examination of the data that revealed the possible presence of offence patterns within mobile offenders, a TwoStep cluster analysis was performed to support this exploratory investigation. For the purpose of this analysis, a new variable was first created to take into account the level of mobility of these offenders. On the basis of the median number of locations used by mobile offenders (i.e., three), a dichotomous variable measuring whether more than two locations or not was used was introduced (40 percent of mobile 
offenders used two locations for abuse, while 60 percent used three locations or more for abuse).

Three offence patterns emerged from the TwoStep cluster analysis. The first offence pattern identified is the 'Familial-low mobility offence' pattern. This pattern is mainly represented by offenders who abuse within a familial setting without using more than two locations for sexual contact. Younger victims are targeted, while violence and penetration rarely occurs. The offence typically takes place for a short period of time and only involves a few sexual episodes. The 'Non familial-high mobility offence' is the second pattern identified. Contrary to the 'Familial-low mobility offence', this pattern comprises offenders who use several locations to have sexual activities with a victim outside the familial setting. It also involves older victims and the occurrence of penetration. The abuse typically does not take place for a long period of time. The third pattern emerging from the data is the 'Familial-high mobility offence'. This offence pattern consists of offenders who use several locations to obtain sexual activities with a victim within their family. It also involves younger victims and violence is likely. This type of offence is characterized by a high level of intrusiveness. It always involves more than ten sexual episodes, and penetrative behaviours. The abuse takes place for more than one year.

INSERT TABLE 3

Displayed in Table 4 are descriptive data on the locations used by each mobile offender within each offence pattern. More specifically, the exact location(s) used, the location(s) most often used and the total number of locations are presented. As seen before in Figure 2, going for a car ride with the child was the most common location/situation for abuse among outdoor locations. Findings further revealed that the 
use of this location is mainly concentrated within the 'Familial low-mobility offence' subgroup. In fact, it was used by 67 percent of offenders (8 offenders out of 12), and 42 percent of them further often used that location/situation for abuse. The frequent use of outdoor locations as part of the offence pattern is also a characteristic of this subgroup. A total of 58 percent of offenders most often used an outdoor location as part of their mobility pattern. Interestingly, the 'Non familial-high mobility offence' subgroup is characterized by the absence of outdoor locations. Only two offenders often used outdoor locations for abuse (e.g., going for a car ride, isolated place outdoor, bush, and taking the child other places). The 'Familial-high mobility offence' subgroup is represented by offenders who used many different indoor and outdoor locations as part of their pattern. These offenders are the most mobile subgroup (mean $=4.42$ ). Once again, only two offenders often used outdoor locations for abuse (i.e., going for a car ride and isolated place outdoor). It should be noted that for all these subgroups, the offender's home is still the most common location used for sexual contact (72 percent).

\section{INSERT TABLE 4}

\section{DISCUSSION}

In the present study, geographic mobility of child sex offenders was examined. An issue of interest is that offenders who used multiple locations for sexual contact are more likely to isolate their victim than single-location offenders. In other words, offenders who switch from one location to another in order to have sexual contact are more likely to spend time alone with their victim. These offenders are perhaps more successful in isolating the victim because they are able to adapt themselves to the situation and switch from one location to another if risks of being seen or caught by a guardian are perceived as high. For instance, an offender may have abused the victim 
several times in his home, but went for a car ride once with the victim because somebody else was home. Based on journey to crime literature and more specifically on the leasteffort principle, it should be expected that most offenders would try to minimize efforts and choose a location that requires the shortest distance to be travelled (Rossmo, 2000). From a rational choice point of view (Cornish \& Clarke, 1986; 2008), a greater distance may be perceived as an additional cost for offending. Translated to child sex offenders' mobility patterns as defined in this study, this would suggest that offenders tend to use a single location for offending and avoid having to move from one location to another. Two factors must be pointed out in relation to this hypothesis, the awareness space of the offender and his motivation to offend. Highly motivated offenders who have a good knowledge of their surroundings may be more likely to move and used different locations for abuse (Brantingham and Brantingham, 1981; Felson, 2006). If offenders are willing to move, they have more options to choose from in order to avoid the presence of guardianship. Using multiple locations is perhaps a prerequisite for offenders who seek to spend more time alone with their victim and pursue with the abuse over a long period of time.

Time alone with the victim does not only reduce risks of interruption or apprehension by a capable guardian. It also provides the opportunity to better control the victim and go on with the abuse. It was found that mobile offenders are more likely to use violence, involve the victim in many sexual episodes for a long period of time, and make him/her participate in sexual activities. If alone with the victim, the offender can use violence to overcome resistance and make the victim comply or perform sexual contact. Being alone with the victim also means that the time spent by the offender for sexual contact should be more considerable. The offender can then repeatedly involved the victim in sexual contact and try to maintain this type of relationship for a long period of 
time. If alone with the victim, the offender also has more time to use manipulation by using various strategies in order to make him/her participate in sexual activities (Leclerc et al., 2008).

Offending patterns of mobile offenders were also identified. Two offence patterns involve high offender mobility (Non familial-high mobility offence, and Familial-high mobility offence). By definition, in both patterns, offenders are using multiple locations for repetitive sexual contact. These patterns are further characterized by a high investment in sexual activities (i.e., involve more than ten sexual episodes and the occurrence of penetration). Once again, it suggests that the awareness space and the motivation to offend are part of the explanation. The offender who uses multiple locations for extended and intrusive sexual activities should have a good knowledge of safe locations around his home and a willingness to switch from one location to another for sexual contact. Based on the current findings, the setting and the age of the victim also shape the offence patterns which is consistent with recent studies completed with sex offenders (Beauregard et al., 2007; Leclerc, Proulx, Lussier, \& Allaire, 2009; Wortley \& Leclerc, 2008). Some high-mobile offenders sexually abuse young victims in a familial setting and others sexually offend against old victims in a non familial setting. Compared to the latter, the former pattern is further characterized by the use of violence. Moreover, in all cases, the abuse took place for over a year and involved more than ten sexual episodes. In fact, younger victims can be more easily manipulated and a certain form of reciprocity can be developed with them. In that context, the offender can use violence if the victim resists without much risks of apprehension. The victim would not tell. Coupled with a familial setting, it provides the offender with an opportunity to abuse the same victim for a long period of time. On the other hand, older victims, coming from a non familial setting are perhaps more willing to have sexual contact with the offender in the 
first place which is consistent with the absence of violence. Some of these victims may simply engage in sexual activities with the offender in exchange for money, alcohol, drugs or other favours. In fact, the abuse does not take place for a long period of time.

The third pattern found is the 'Familial-low mobility offence'. This pattern comprises offenders who do not use multiple locations for sexual contact. They also abuse young victims within a familial setting. The offence is characterized by a low investment in sexual activities (i.e., the offence takes place for a short period of time, it does not involve several sexual episodes, and penetration rarely occurs). This offence pattern is perhaps mainly represented by opportunity takers. Most of these offenders may not be very motivated to invest time with a child for extended sexual activities in the first place. These offenders are ambiguous in their criminal commitment and opportunistic in their offending (Cornish \& Clarke, 2003; Smallbone et al., 2008; Wortley, 2008). That is why they do not use multiple locations for abuse. They just seize some opportunities within their immediate family to have sexual contact with a vulnerable person.

Following the identification of these offence patterns, the objective was to link these profiles back to the exact locations where the abuse was perpetrated. In this study, 72 percent of mobile offenders still used their own home for abuse on a regular basis. To reduce risks of interruption by a capable guardian, and maximize benefits, offenders need to select safe locations such as indoor places (i.e., offender's home, child's home, friend's home). Among these places, the offender's home is perhaps the most attractive choice. For offenders, their own home provides greater scope to control the situation and manage the risks and rewards associated with having sexual activities with children. Offenders have greater control over who might enter the setting and possibly interfere with the commission of the crime. There is no-one to witness the offence and if the victim resists or makes a noise, it is easier to overcome him/her without increasing the risks of 
apprehension. Offenders also have more time to commit the crime and thus more time to get their victim involved in sexual activity. This finding is consistent with Beauregard and Leclerc's (2007) recent research indicating that most sexual offenders take into account risks of apprehension before committing their crime. The absence of possible witnesses and the presence of a favourable environment for crime to occur were reported by offenders as some of the main reasons for assessing risks of apprehension as low before choosing to commit their crime. On the other hand, public or outside places were considered as risky environments by offenders.

Findings also revealed that the 'Familial-low mobility offence' pattern is characterized by the use of a car ride as a location/situation for abuse. Recall that going for a car ride was also the most common outdoor location used by offenders overall (see Figure 2). Going for a car ride for sexual contact is actually a good trade-off for the offender if somebody else is home. It is an easy strategy to implement (i.e., just get in the car), and to justify (e.g., the offender can say that he is going to the groceries). The most important characteristic is that the car is still a private place. Nobody would normally look into someone else's car especially when it is occupied. Consequently, sexual contacts are still safe from possible witnesses and the likelihood that a possible guardian would interfere is kept low unless the victim resists. Another important element is that the offender can drive his victim to wherever he wants whenever he wants. The offender can travel with his victim to find the safest area for sexual contact. If something happens or a guardian shows up, he can drive away. Going for a car ride provides a good opportunity for abuse. Within this subgroup, offenders also generally more often use outdoor locations than in other offence patterns. If it is assumed that this pattern is followed mostly by opportunity-takers type of offenders, the actual location may not matter much for them. Once again, as long as no capable guardian can immediately 
witness or disrupt the offence, offenders may decide to proceed on-the-spot wherever they are.

The high mobility offence patterns (i.e., familial and non familial) were found to be characterized by the low incidence of outdoor locations. The 'Familial' subgroup was further found to include the most mobile offenders of all (average of 4.42 locations by offender). These findings suggest that these offenders display a large awareness space and possibly an efficient decision-making process. They manage to switch frequently from one location to another without having to venture out on a regular basis. By doing so, they avoid risks of interruption and apprehension. Recall that decisions about how to travel and where to travel are assumed to be based on knowledge of the area, previous experience, and expectations about the result of travelling (Brantingham \& Brantingham, 1984). In other words, high mobility offenders are possibly committed offenders (Cornish \& Clarke, 2003; Smallbone et al., 2008; Wortley, 2008). They know what they are doing.

\section{Limitations}

As this study is perhaps the first to focus on the use of multiple locations for sexual contact in child sex offending, the results need to be interpreted accordingly. This study also has some limitations. First, the small sample size limits the analyses that could have been completed. Consequently, the findings of this study are rather exploratory. Second, geographic mobility was defined as the use of multiple locations for repetitive sexual contact. Geographic mobility could have been defined differently. More specifically, it could have been defined as comprising different types of locations of the same classification (e.g., two different parks would be considered as two different locations). Data used in this study, however, do not provide details of whether the offender used different types of locations from the same classification. Third, the sample 
used in this study contains offenders who had only one victim. Future studies should pay attention to offender mobility of child sex offenders across life-course. For instance, an offender may use a single location to abuse his first victims and then use multiple locations for subsequent victims. Finally, note that the present study is based on selfreport data, which means that some findings may be partially biased by poor memory recall or offender cognitive distortions.

\section{CONCLUSION}

In the present study, geographic mobility of child sex offenders was examined. By examining the geographic mobility of offenders from another point of view, an alternative way of addressing offender mobility in child sex offending was provided. Offender mobility does not only refer to the concepts of distance or direction as currently used in the journey-to-crime literature. In the child sex offending area, offender mobility should be analysed from different angles for better understanding the crime-commission process of these offenders. The approach used in this study can be especially useful in the context of interpersonal offences where the offender and the victim repeatedly converge in time and space generating multiple incidents (i.e., child sex offending, domestic violence, bullying, etc.).

A practical outcome of such research is that it may help designers of prevention measures to develop techniques tailored to reach specific groups of offenders. For instance, as the offender's home is the most common location for abuse and is also the most difficult place in which to implement situational measures (Smallbone et al., 2008), mobile offending patterns were emphasized. The rationale was that if some offenders are using multiple or other locations for abuse than their own home, it may offer other options for prevention purposes. These offenders may be easier to reach at other 
offending locations. First, it was found that the 'Familial-low mobility offence' subgroup is quite likely to go for a car ride with the victim for sexual contact. Interestingly, going for a car ride was also the most common outdoor location across all subgroups. A car provides privacy and mobility. The offender can easily drive somewhere else if he needs to. If we follow Brantingham and Brantingham’s (1993) concept of awareness space, offenders would not randomly select locations for sexual contact. Rather, they would use locations that they are aware of and where they can easily go to. As the awareness space of offenders is limited, increasing surveillance (e.g., implementation of closed-circuit television) and restricting the access (e.g., place managers) to specific public areas where offenders go with their car to have sexual activities with a child would reduce opportunities for offending. At the same time, reducing offenders' repertoire of places can force them to use locations of which they do not have a good knowledge. In these situations, offenders would perhaps expose themselves to further risk of apprehension. Second, it was found that high mobility offenders rarely use outdoor locations. It thus suggests that private residences (e.g., offender's home, victim's home, friend or relative's home) are still of high importance for prevention. These locations are, however, difficult to access for that purpose. Perhaps in these cases the location of crime is not the best input to start with to prevent child sex offending from occurring. Analysing the crime commission process of child sex offenders offers valuable intervention points for prevention (Leclerc et al., 2008). It may prove to be an interesting complementary tool to take into account in this context for purposes of situational prevention.

Lastly, such investigation may also help practitioners and probation officers involved in managing sex offenders in the community. As pointed out by Levenson and Cotter (2005), residency restrictions should be sensible, feasible and based on a thorough assessment of offence patterns. Like any prevention or policy measures, residency 
restrictions must be based on empirical findings. Motivated offenders are willing to travel great distance to reoffend and will look for locations where risks of getting caught are kept to a minimum (Levenson and Cotter, 2005). The present study further suggests the existence of different subgroups of mobile offenders who will use several locations for sexual contact and abuse the same victim for a long period of time. These findings could be helpful for practitioners in determining appropriate supervision restrictions for offenders. In any event, more research must be completed on the geographic mobility of child sex offenders and their offending behaviours. This study was the first to focus on geographic mobility of child sex offenders as defined as the use of multiple locations to abuse the same victim over a period of time. Other studies are essential before proposing clear guidelines in regards to any potential prevention and policy implications. It is hoped that this study was a step forward towards that direction.

\section{ACKNOWLEDGEMENTS}

The authors would like to thank Eric Beauregard for comments made on an earlier version of this manuscript. This study was supported by a grant from the Social Sciences and Humanities Research Council of Canada (SSHRC) (756-2007-0032).

\section{REFERENCES}

Beauregard, E., \& Leclerc, B. (2007). An application of the rational choice approach to the offending process of sex offenders: A closer look at the decision-making. Sexual Abuse: A Journal of Research and Treatment, 19, 115-133.

Beauregard, E., Proulx, J., Rossmo, D.K., Leclerc, B., \& Allaire, J.F. (2007). Script analyses of the hunting process of serial sex offenders. Criminal Justice and Behavior, 34, 1069-1084. 
Bennett, T., \& Wright, R. (1984). Burglars on burglary: Prevention and the offender. Aldershot: Gower.

Bernasco, W., \& Nieuwbeerta, P. (2005). How do residential burglars select target areas? British Journal of Criminology, 44, 296-315.

Block, R., Galary, A., \& Brice, D. (2007). The journey to crime: Victims and offenders converge in violence index offenses in Chicago. Security Journal, 20, 123-137.

Brantingham, P.J., \& Brantingham, P.L. (1978). A theoretical model of crime site selection. In M. Krohn \& R. Akers (Eds.), Crime, law, and sanctions (pp.105-118). Beverly Hills, CA: Sage.

Brantingham, P.J., \& Brantingham, P.L. (1981). Notes on the geometry of crime. In P. Brantingham \& P. Brantingham (Eds.), Environmental criminology (pp. 27-54). Beverley Hills, CA: Sage.

Brantingham, P.J., \& Brantingham, P.L. (1984). Patterns in crime. New York: MacMillan.

Brantingham, P.L., \& Brantingham, P.J. (1993). Environment, routine and situation: Toward a pattern theory of crime. In R.V. Clarke \& M. Felson (Eds.), Routine activity and rational choice (pp.259-294). New Brusnwick, NJ: Transaction.

Carroll, J., \& Weaver, F. (1986). Shoplifters’ perceptions of crime opportunities: A process-tracing study. In D. B. Cornish \& R. V. Clarke (Eds.), The reasoning criminal: Rational choice perspectives on offending (pp. 19-38). New York: Springer-Verlag.

Cohen, L.E.. \& Felson, M. (1979). Social change and crime rate trends: A routine activity approach. American Sociological Review, 44, 588-608. 
Cornish, D.B. (1994). The procedural analysis of offending and its relevance for situational prevention. In R.V. Clarke (Ed.), Crime prevention studies: Vol. 3 (pp. 151-196). Monsey, NY: Criminal Justice Press.

Cornish, D.B., \& Clarke, R.V. (1986). Introduction. In D.B. Cornish \& R.V. Clarke (Eds.), The reasoning criminal: Rational choice perspectives on offending (pp. 1-16). New York: Springer-Verlag.

Cornish, D.B., \& Clarke, R.V. (2003). Opportunities, precipitators and criminal decisions: A reply to Wortley’s critique of situational crime prevention. In M.J. Smith \& D.B. Cornish (Eds.), Crime prevention studies: Vol. 16. Theory for practice in situational crime prevention (pp. 41-96). Monsey, NY: Criminal Justice Press.

Cornish, D.B., \& Clarke, R.V. (2008). The rational choice perspective. In R. Wortley \& L. Mazerolle (Eds.), Environmental criminology and crime analysis (pp. 21-47). Cullompton, UK: Willan.

Coupe, T., \& Blake, L. (2006). Daylight and darkness targeting strategies and the risks of being seen at residential burglaries. Criminology, 44, 431-464.

Cromwell, P., Olson, J., \& Avary, D’A. W. (1991). Breaking and entering: An ethnographic analysis of burglary. Newbury Park, CA: Sage.

Duwe, G., Donnay, W., \& Tewksbury, R. (2008). Does residential proximity matter? A geographic analysis of sex offense recidivism. Criminal Justice and Behavior, 35, 484-504.

Eck, J. (1995). A general model of the geography of illicit retail marketplaces. In J. Eck \& D. Weisburd (Eds.), Crime prevention studies: Vol. 4. Crime and place (pp. 6793). Monsey, NY: Criminal Justice Press. 
Eck, J. \& Weisburd, D. (1995). Crime places in crime theory. In J. Eck \& D. Weisburd (Eds.), Crime prevention studies: Vol. 4. Crime and place (pp. 1-33). Monsey, NY: Criminal Justice Press.

Elliott, M., Browne, K., \& Kilcoyne, J. (1995). Child sexual abuse prevention: What offenders tell us. Child Abuse and Neglect, 19, 579-594.

Feeney, F. (1986). Robbers as decision-makers. In D. B. Cornish \& R. V. Clarke (Eds.), The reasoning criminal: Rational choice perspectives on offending (pp. 53-71). New York: Springer-Verlag.

Felson, M. (1986). Linking criminal choices, routine activities, informal control, and criminal outcomes. In D.B. Cornish \& R.V. Clarke (Eds.), The reasoning criminal: Rational choice perspectives on offending (pp.119-128). New York: Springer-Verlag.

Felson, M. (1995). Those who discourage crime. In J. Eck \& D. Weisburd (Eds.), Crime prevention studies: Vol. 4. Crime and place (pp. 53-66). Monsey, NY: Criminal Justice Press.

Felson, M. (2006). Crime and nature. Thousand Oaks, CA: Sage.

Gabor, T. \& Gottheil, E. (1984). Offender characteristics and spatial mobility: An empirical study and some policy implications. Canadian Journal of Criminology, 26, 267-281.

Kaufman, K. L. (1989). Modus operandi questionnaire. Columbus, OH: Children’s Hospital.

Kaufman, K.L., Hilliker, D.R., \& Daleiden, E.L. (1996). Subgroup differences in the modus operandi of adolescent sexual offenders. Child Maltreatment, 1, 17-24.

Lang, R.A., \& Frenzel, R.R. (1988). How sexual offenders lure children. Annals of Sex Research, 1, 303-317. 
LeBeau, J. L. (1987). The journey to rape: Geographic distance and the rapist’s method of approaching the victim. Journal of Police Science and Administration, 15, 129136.

Leclerc, B., Proulx, J., Lussier, P., \& Allaire, J.-F. (2009). Offender-victim interaction and crime event outcomes: Modus operandi and victim effects on the risk of intrusive sexual offences against children. Criminology, 47, 595-618.

Leclerc, B., \& Tremblay, P. (2007). Strategic behavior in adolescent sexual offenses against children: Linking modus operandi to sexual behaviors. Sexual Abuse: A Journal of Research and Treatment, 19, 23-41.

Leclerc, B., Wortley, R., \& Smallbone, S. (2008, July). Getting into the script of adult child sex offenders. Paper presented at the International Symposium on Environmental Criminology and Crime Analysis, Anchorage, Alaska.

Levenson, J.S., \& Cotter, L.P. (2005). The impact of sex offender residence restrictions: 1,000 feet from danger or one step from absurd? International Journal of Offender Therapy and Comparative Criminology, 49, 168-178.

Lundrigan, S., \& Czarnomski, S. (2006). Spatial characteristics of serial sexual assault in New Zealand. Australian and New Zealand Journal of Criminology, 39, 218-231.

Nee, C., \& Meenaghan, A. (2006). Expert decision making in burglars. British Journal of Criminology, 46, 935-949.

Petrosino, A., \& Brensilber, D. (2003). The motives, methods and decision-making of convenience store robbers: Interviews with 28 incarcerated offenders in Massachusetts. In M. J. Smith \& D. B. Cornish (Eds.), Crime prevention studies, Vol. 16. Theory for practice in situational crime prevention (pp. 237263). Monsey, NY: Criminal Justice Press. 
Rengert, G. F. (2004). The journey to crime. In G. Bruinsma, H. Elffers, \& J. de Keijser (Eds.), Punishment, places and perpetrators: Development in criminology and criminal justice research (pp. 169-181). Portland, OR: Willan.

Rengert, G., \& Wasilchick, J. (2000). Suburban burglary: A tale of two suburbs (2 ${ }^{\text {nd }}$ ed.). Springfield, IL: Charles C. Thomas.

Rhodes, W., \& Conly, C. (1981). Crime and mobility: An empirical study. In P.J. Brantingham \& P.L. Brantingham (Eds.), Environmental criminology (pp.167-188). Beverley Hills, CA: Sage.

Rossmo, D.K. (2000). Geographic profiling. Boca Raton, FL: CRC Press.

Smallbone, S., Marshall, W.L., \& Wortley, R.K. (2008). Preventing child sexual abuse: Evidence, policy and practice. Cullompton, Devon, UK: Willan Publishing.

Smallbone, S. \& Wortley, R. (2000). Child sexual abuse in Queensland: Offender characteristics and modus operandi. Brisbane, Australia: Queensland Crime Commission.

Tewksbury, R., \& Mustaine, E. (2006). Where to find sex offenders: An examination of residential locations and neighborhood conditions. Criminal Justice Studies, 19, 6175.

Walker, J.T., Golden, J.W., \& VanHouten, A.C. (2001). The geographic link between sex offenders and potential victims: A routine activities approach. Justice Research and Policy, 3, 15-33.

Walsh, D. (1986). Victim selection procedures among economic criminals: The rational choice perspective. In D. B. Cornish \& R. V. Clarke (Eds.), The reasoning criminal: Rational choice perspectives on offending (pp. 39-52). New York: Springer-Verlag. 
Wortley, R. (2008). Situational precipitators of crime. In R. Wortley \& L. Mazerolle (Eds.), Environmental Criminology and Crime Analyses (pp. 48-69). Cullompton, UK: Willan.

Wortley, R., \& Leclerc, B. (2008, March). Child sexual abuse in Aboriginal communities. Paper presented at the Environmental criminology and crime analysis annual meeting, Izmir, Turkey.

Wortley, R., \& Smallbone, S. (2006). Applying situational principles to sexual offenses against children. In R. Wortley \& S. Smallbone (Eds.), Crime prevention studies: Vol. 19. Situational prevention of child sexual abuse (pp. 7-35). Monsey, NY: Criminal Justice Press.

Wright, R., \& Decker, S. (1994). Burglars on the job: Streetlife and residential breakins. Boston: Northeastern University Press.

Wright, R., \& Decker, S. (1997). Armed robbers in action: Stickups and street culture. Boston: Northeastern University Press.

Wright, R., \& Logie, R. (1988). How young house burglars choose targets. Howard Journal of Criminal Justice, 27, 92-104.

Wright, R., Logie, R., \& Decker, S. (1995). Criminal expertise and offender decisionmaking: An experimental study of the target selection process in residential burglary. Journal of Research in Crime and Delinquency, 32, 39-53.

Zipf, G. (1950). The principle of least effort. Reading, MA: Addison Wesley. 
FIGURE 1. Geographic Mobility of Offenders for Two Types of Offences

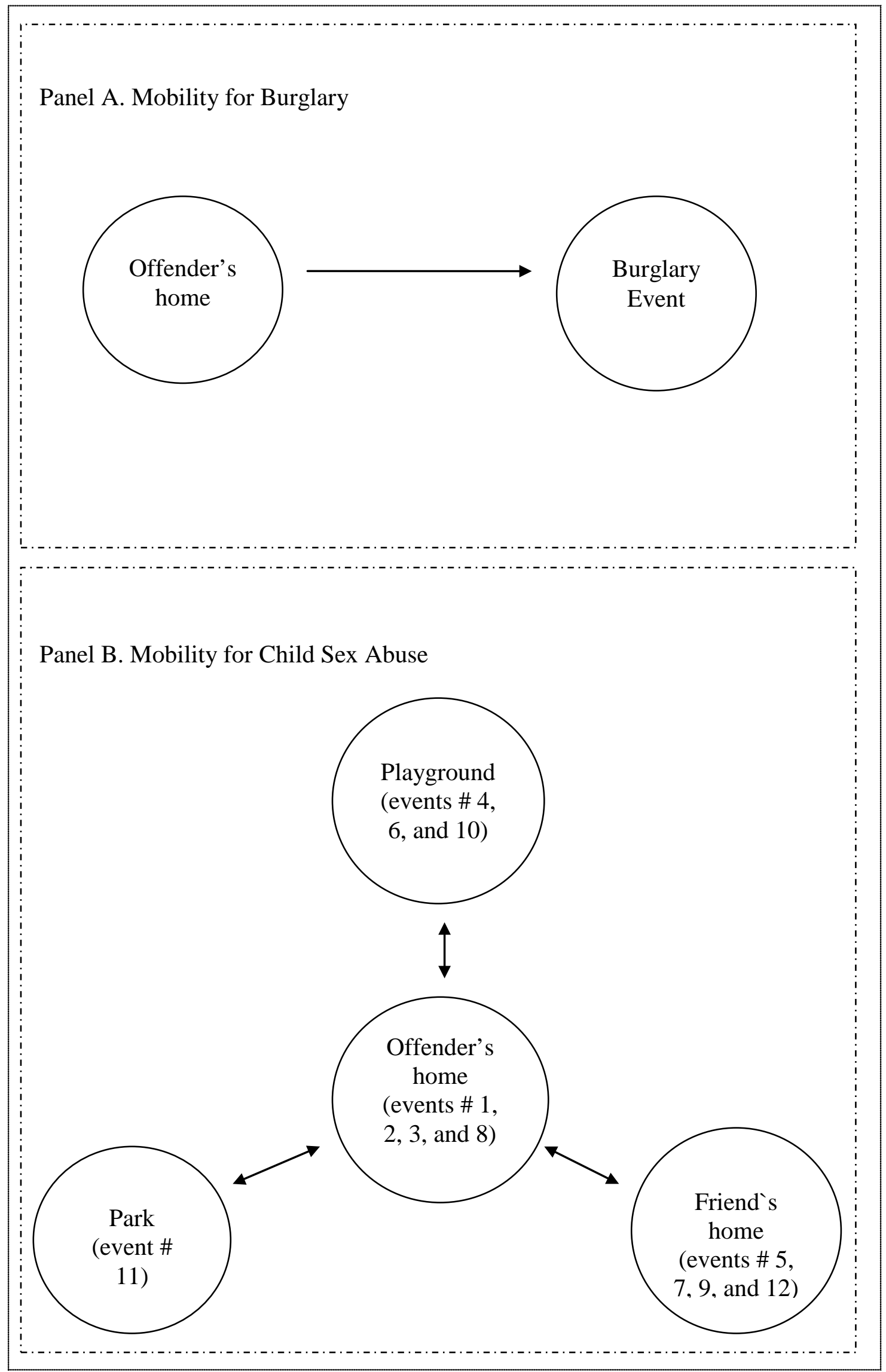


TABLE 1 . Locations used by offenders for sexual contact $(n=77)$

\begin{tabular}{ll}
\hline Locations & $\%(\mathrm{n})$ \\
\hline Offender's home & $84.4 \%(65)$ \\
Out of the way place in child's home & $15.6 \%(12)$ \\
Friend/relative's home & $9.1 \%(7)$ \\
Take child for a car ride & $18.2 \%(14)$ \\
Isolated places outdoor (e.g., vacant lot) & $18.2 \%(14)$ \\
Park & $2.6 \%(2)$ \\
Bush & $10.4 \%(8)$ \\
Movie theatre & $1.3 \%(1)$ \\
Public toilet & $1.3 \%(1)$ \\
Swimming pool & $1.3 \%(1)$ \\
Take child for walks & $5.2 \%(4)$ \\
Playground & $0 \%(0)$ \\
\hline
\end{tabular}


FIGURE 2. Number of Offenders by Locations of Abuse $(n=77)^{\mathrm{a}}$

Panel A. Offenders using multiple locations $(n=25)$

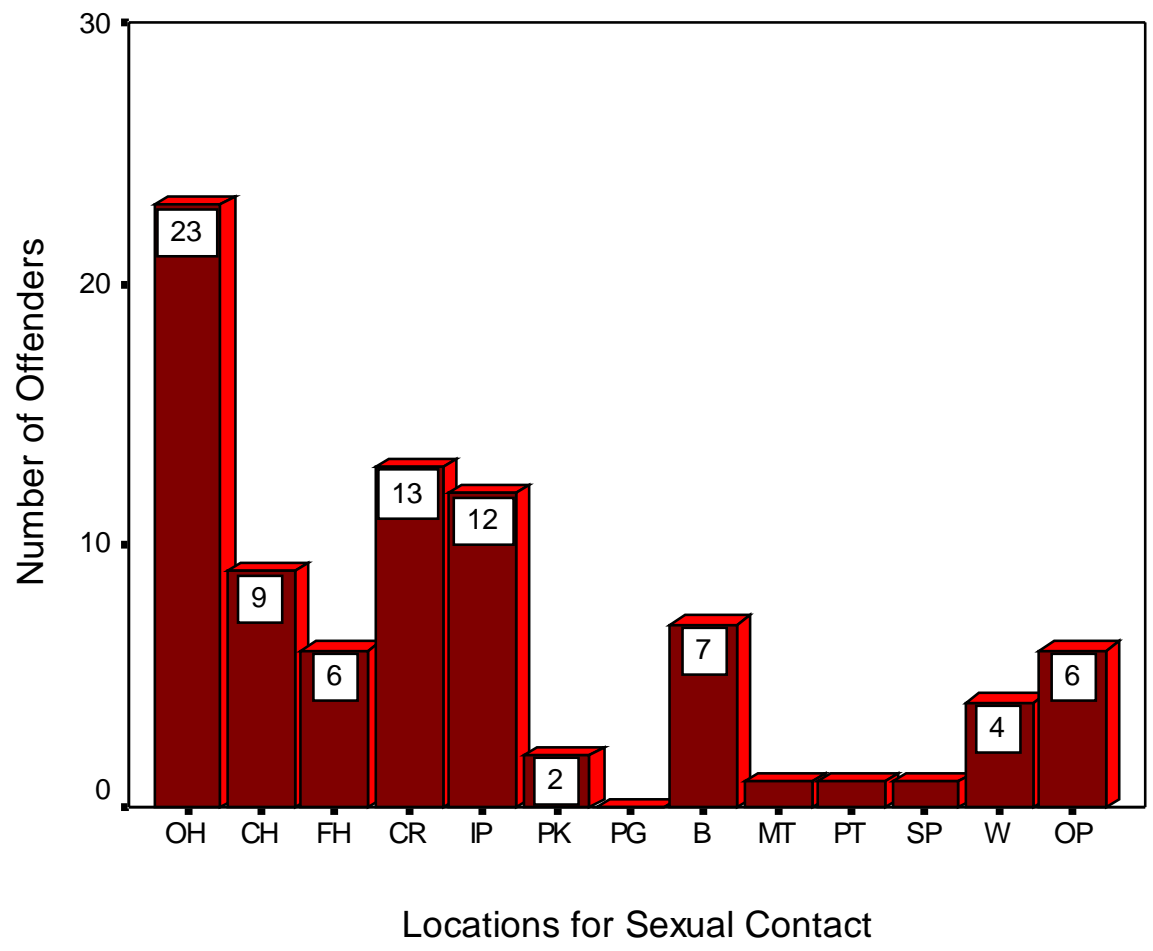

Panel B. Offenders using a single location $(n=52)$

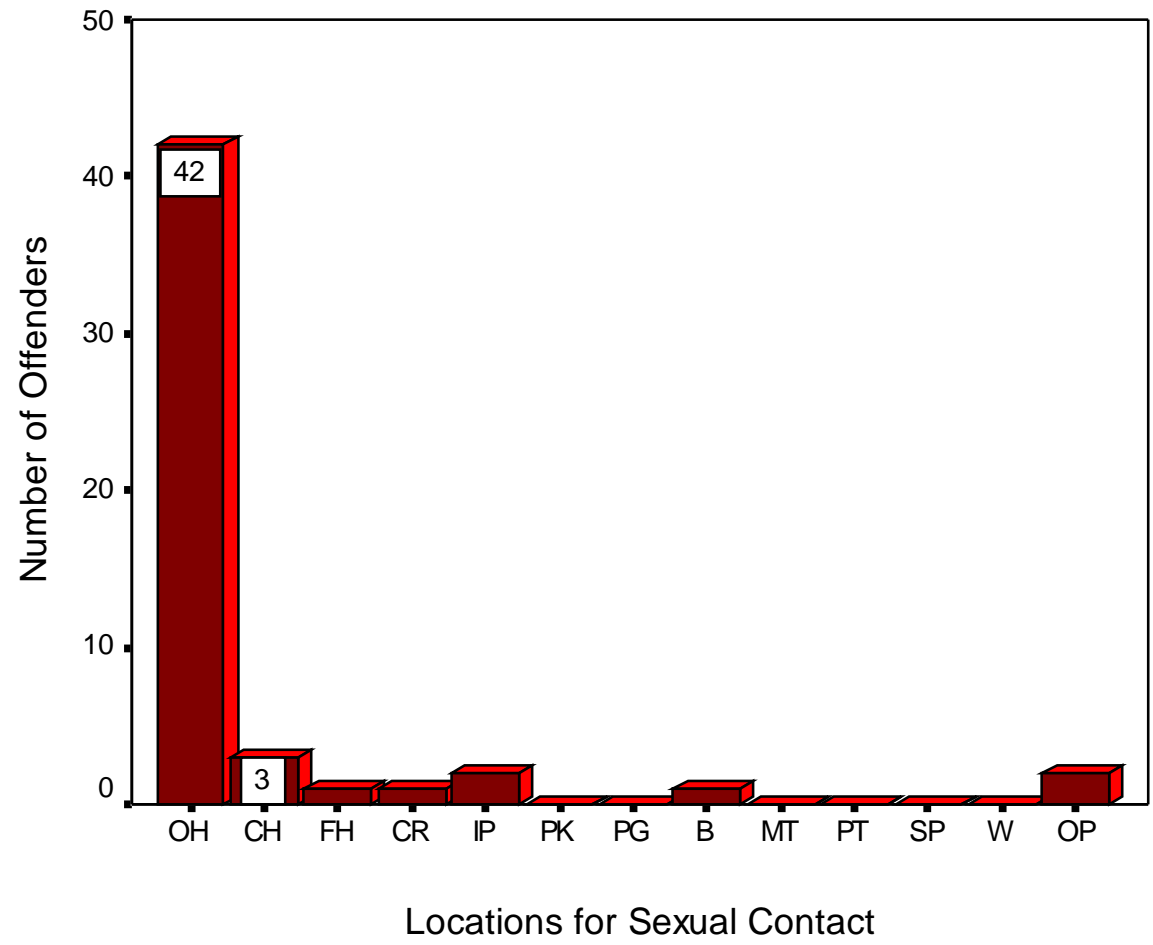

a. $\mathrm{OH}=\mathrm{Offender}$ 's home, $\mathrm{CH}=\mathrm{Out}$ of the way place in child's home, $\mathrm{FH}=$ Friend/relative's home, $\mathrm{CR}=$ Take child for a car ride, $\mathrm{IP}=$ Isolated places outdoor (e.g., vacant lot), $\mathrm{PK}=\mathrm{Park}, \mathrm{PG}=$ Playground, $\mathrm{B}=\mathrm{Bush}, \mathrm{MT}=$ Movie theatre, $\mathrm{PT}=\mathrm{Public}$ toilet, $\mathrm{SP}=$ Swimming pool, $\mathrm{W}=$ Take child for walks, $\mathrm{OP}=$ Take child other places. 
TABLE 2. Offence Characteristics by Geographic Mobility for Sexual Contact $(n=77)$

\begin{tabular}{|c|c|c|c|c|}
\hline Variables & $\begin{array}{l}\text { Single-Location } \\
\text { Offenders } \\
(67.5 \% ; n=52)\end{array}$ & $\begin{array}{l}\text { Multiple- } \\
\text { Locations } \\
\text { Offenders } \\
(32.5 \% ; n=25) \\
\end{array}$ & & \\
\hline & $\%$ & $\%$ & Chi-square & $p$ \\
\hline The victim was a girl & $90.4 \%$ & $88 \%$ & .103 & .710 \\
\hline $\begin{array}{l}\text { The victim was } 13 \\
\text { years or older }\end{array}$ & $48.1 \%$ & $36 \%$ & .999 & .318 \\
\hline $\begin{array}{l}\text { Isolated the child for } \\
\text { sexual contact }\end{array}$ & $72.5 \%$ & $92 \%$ & 3.189 & .051 \\
\hline $\begin{array}{l}\text { Offence occurred in a } \\
\text { familial setting }\end{array}$ & $75 \%$ & $72 \%$ & .079 & .779 \\
\hline $\begin{array}{l}\text { Offender used } \\
\text { violence }\end{array}$ & $7.7 \%$ & $32 \%$ & 7.583 & .015 \\
\hline $\begin{array}{l}\text { More than } 10 \text { sexual } \\
\text { episodes occurred }\end{array}$ & $28.8 \%$ & $56 \%$ & 5.302 & .021 \\
\hline $\begin{array}{l}\text { Sexual episodes lasted } \\
\text { for more than } 5 \\
\text { minutes }\end{array}$ & $66 \%$ & $80 \%$ & 1.450 & .229 \\
\hline $\begin{array}{l}\text { The abuse took place } \\
\text { over a year }\end{array}$ & $23 \%$ & $48 \%$ & 4.888 & .027 \\
\hline $\begin{array}{l}\text { Victim participation } \\
\text { in sexual episodes } \\
\text { occurred }\end{array}$ & $57.7 \%$ & $84 \%$ & 5.225 & .022 \\
\hline $\begin{array}{l}\text { Penetration was } \\
\text { performed on the } \\
\text { victim }\end{array}$ & $51.9 \%$ & $60 \%$ & .444 & .505 \\
\hline
\end{tabular}


TABLE 3. Three Offence Patterns Identified within Mobility Offending ( $n=25)$

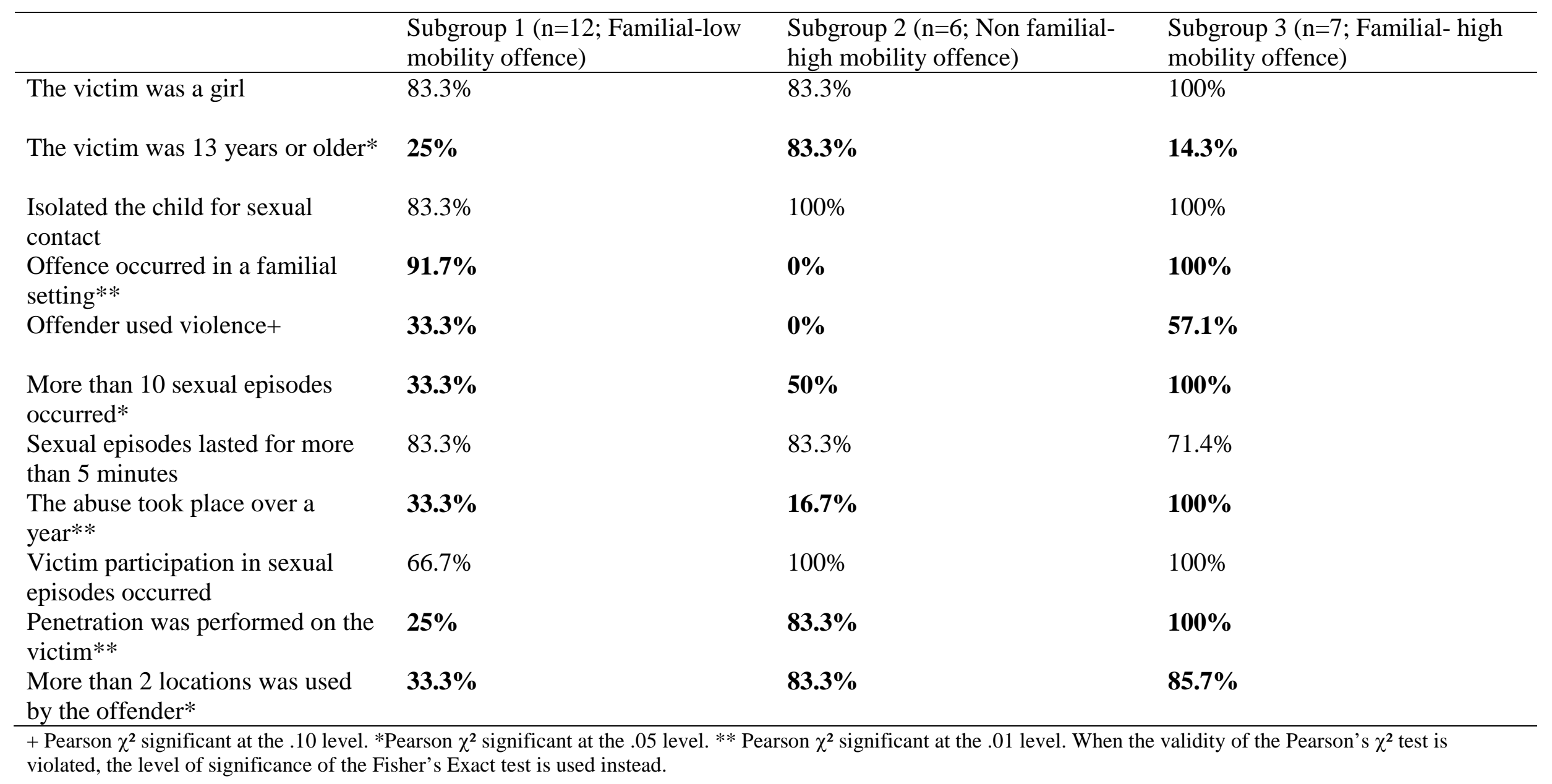


TABLE 4. Descriptive Data for Locations Used by Subgroups of Mobile Offending Patterns in Child Sex Abuse $(n=25)^{\mathrm{a}}$

\begin{tabular}{|c|c|c|c|}
\hline & $\begin{array}{l}\text { Locations } \\
\text { used }\end{array}$ & $\begin{array}{l}\text { Location(s) most } \\
\text { often used }\end{array}$ & $\begin{array}{l}\text { Total number of } \\
\text { locations }\end{array}$ \\
\hline \multicolumn{4}{|c|}{$\begin{array}{l}\text { Subgroup } 1 \\
\text { (Familial-low } \\
\text { mobility offence) }\end{array}$} \\
\hline 1 & $\mathrm{OH}, \mathrm{CH}$ & $\mathrm{CH}$ & 2 \\
\hline 2 & $\mathrm{OH}, \mathrm{IP}$ & IP & 2 \\
\hline 3 & $\mathrm{OH}, \mathrm{CR}, \mathrm{OP}$ & $\mathrm{OH}$ & 3 \\
\hline 4 & $\mathrm{OH}, \mathrm{CR}$ & $\mathrm{OH}$ & 2 \\
\hline 5 & $\mathrm{OH}, \mathrm{CR}$ & $\mathrm{OH}, \mathrm{CR}$ & 2 \\
\hline 6 & $\begin{array}{l}\text { OH, CH, FH, CR, IP, } \\
\text { MT }\end{array}$ & $\begin{array}{l}\text { OH, CH, FH, CR, IP, } \\
\text { MT }\end{array}$ & 6 \\
\hline 7 & $\mathrm{OH}, \mathrm{IP}, \mathrm{W}$ & $\mathrm{OH}$ & 3 \\
\hline 8 & $\mathrm{OH}, \mathrm{IP}$ & OH, IP & 2 \\
\hline 9 & $\begin{array}{l}\mathrm{OH}, \mathrm{CH}, \mathrm{CR}, \mathrm{IP}, \mathrm{B} \text {, } \\
\mathrm{W}\end{array}$ & $\begin{array}{l}\mathrm{OH}, \mathrm{CH}, \mathrm{CR}, \mathrm{IP}, \mathrm{B}, \\
\mathrm{W}\end{array}$ & 6 \\
\hline 10 & $\mathrm{OH}, \mathrm{CR}$ & $\mathrm{OH}$ & 2 \\
\hline 11 & CR, PK & CR, PK & 2 \\
\hline 12 & $\mathrm{OH}, \mathrm{CR}$ & $\mathrm{OH}, \mathrm{CR}$ & 2 \\
\hline Mean & - & - & 2.83 \\
\hline \multicolumn{4}{|c|}{$\begin{array}{l}\text { Subgroup } 2 \\
\text { (Non familial-high } \\
\text { mobility offence) }\end{array}$} \\
\hline 13 & FH, CR, IP, B & FH, CR, IP, B & 4 \\
\hline 14 & $\mathrm{OH}, \mathrm{IP}, \mathrm{B}$ & $\mathrm{OH}$ & 3 \\
\hline 15 & $\mathrm{OH}, \mathrm{FH}$ & $\mathrm{OH}$ & 2 \\
\hline 16 & $\mathrm{OH}, \mathrm{FH}, \mathrm{OP}$ & $\mathrm{OH}, \mathrm{FH}$ & 3 \\
\hline 17 & $\mathrm{OH}, \mathrm{CR}, \mathrm{IP}, \mathrm{B}, \mathrm{OP}$ & $\mathrm{OH}, \mathrm{CR}, \mathrm{IP}, \mathrm{B}, \mathrm{OP}$ & 5 \\
\hline 18 & $\mathrm{OH}, \mathrm{CH}, \mathrm{FH}$ & $\mathrm{CH}$ & 3 \\
\hline Mean & - & - & 3.33 \\
\hline \multicolumn{4}{|c|}{$\begin{array}{l}\text { Subgroup } 3 \\
\text { (Familial- high } \\
\text { mobility offence) }\end{array}$} \\
\hline 19 & $\mathrm{OH}, \mathrm{CH}, \mathrm{W}$ & $\mathrm{OH}, \mathrm{CH}$ & 3 \\
\hline 20 & $\mathrm{OH}, \mathrm{CH}, \mathrm{CR}, \mathrm{IP}, \mathrm{OP}$ & $\mathrm{OP}$ & 5 \\
\hline 21 & $\begin{array}{l}\text { OH, CH, CR, IP, B, } \\
\text { OP }\end{array}$ & $\mathrm{OH}, \mathrm{CH}, \mathrm{CR}, \mathrm{IP}$ & 6 \\
\hline 22 & $\mathrm{OH}, \mathrm{CH}, \mathrm{IP}, \mathrm{B}, \mathrm{W}$ & $\mathrm{OH}, \mathrm{CH}, \mathrm{IP}$ & 5 \\
\hline 23 & $\begin{array}{l}\mathrm{OH}, \mathrm{CH}, \mathrm{CR}, \mathrm{IP}, \mathrm{PK} \text {, } \\
\text { PT, SP }\end{array}$ & $\mathrm{CH}$ & 7 \\
\hline 24 & $\mathrm{OH}, \mathrm{FH}, \mathrm{OP}$ & $\mathrm{OH}$ & 3 \\
\hline 25 & $\mathrm{OH}, \mathrm{B}$ & $\mathrm{OH}$ & 2 \\
\hline Mean & - & 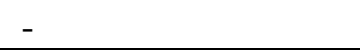 & 4.42 \\
\hline
\end{tabular}

